\title{
Stanisław Brzozowski: Philosophy as biography of thought. A philosophical attempt
}

\author{
Izabela SZYrokA
}

\begin{abstract}
This article considers the most important philosophical work of Stanisław Brzozowski, Ideas. Introduction to the Philosophy of Historical Maturity, as an opportunity to examine the question of what leads some philosophers to set out their philosophical standpoint in the form of a biography of thought. This article poses the following questions: Why is it that an author's biography should subordinate reality to philosophical thought? Do we expect an author to render an account of what kind of man he is, and by what path he came to his convictions concerning every philosophical theory? I would like to demonstrate that it is philosophy that needs biographical testimony. Thus biography becomes a place where man develops some orientation in reality, based on past actions that were recorded, the values assigned to events, the significance given to concrete aspects of his own life, and a multitude of minute facts. By creating himself in the biography of his own thought as a particular character, he builds a foundation for himself to plan the future.
\end{abstract}

Keywords: philosophical anthropology, philosophy and history, biography/autobiography

Dr hab. Izabela Szyroka, lecturer at the Philosophy Institute - Jagiellonian University, her latest book is Autobiografia i filozofia. Próba filozoficzna rozważenia wzajemnych odniesień na podstawie kilku klasycznych przyktadów (Autobiography and Philosophy: a philosophical attempt to examine mutual references on the basis of classic cases), Nomos, Kraków 2016.

E-MAIL: iszyroka@yahoo.com 
The Reviewers have had the kindness of bringing to my attention the existence of the latest book by M. Urbanowski, Stanisław Brzozowski. Nowoczesność (Łódź 2017) as well as the letters of Stanisław Brzozowski, in edition of M. Sroka (Kraków 1970). The author should also like to thank the Reviewer who offered advice and inspiring criticism while pointing out important complementary broadening approach to her own in such areas as the ethical basis for the Stanisław Brzozowski's philosophy of act and the reception of Catholic modernism in Brzozowski's thought.

\section{Philosophy as biography of thought}

"Man is writing well only when he writes himself", Lichtenberg once said. ${ }^{1}$ Can we allow this remark to also include philosophising? Can it be that a good thought - one which is alive and able to appear as a historically shaping power - is based on some intimate, personal, individual experience which is then accounted for by a philosophical system? "Metaphysics, when disentangled, reduces itself to biography and ethical history", was Stanisław Brzozowski's view ${ }^{2}$. "What is not biography possesses no existence at all. What claims the right to any super-biographical, super-concrete, individual meaning is, in point of fact, less real." " "There is one power only: making use of one's own and only life to fertilise time". ${ }^{4}$ Realising this state of affairs, presages true historical maturity, according to the author of Idee. Wstęp do filozofii dojrzałości dziejowej (Ideas. Introduction to the Philosophy of Historical Maturity).

Classifying philosophical works as good or unsuccessful is obviously not the intention of this article; nor do I propose to claim that philosophy not grounded in individual experience is impossible. However, I am interested

${ }^{1}$ G. Ch. Lichtenberg, Schriften und Briefe, hrsg. von Wolfgang Promies (München 1962), [B 95]. Pochwata watpienia. Bruliony i inne pisma, selected and translated to Polish by T. Zatorski (Gdańsk: słowo/obraz terytoria, 2005), p. 51. The first Polish edition of this essay: "Idee. Wstęp do filozofii dojrzatości dziejowej Stanistawa Brzozowskiego jako filozoficzny pamiętnik”, was published in Oblicza Narcyza: obecność autora w dziele, Wydawnictwo Uniwersytetu Jagiellońskiego, Kraków 2008, pp. 435-456.

2 S. Brzozowski, Pamiętnik (Diary), with fragments of the author's letters selected and commented on by O. Ortwin, introduction by A. Mencwel (Warsaw: Czytelnik, 200o), p. 94.

3 Ibidem, p. 126.

4 S. Brzozowski, Idee. Wstęp do dojrzatości dziejowej (Ideas. Introduction to the Philosophy of Historical Maturity), also: Zludzenia racjonalizmu (The Illusions of Rationalism), introduction: A. Walicki (Kraków: Wydawnictwo Literackie, 1990), p. 430. 
in the motives and rationales which cause some authors to outline their philosophical standpoint in the form of a biography of thought. Brzozowski perceives his work as the "diary of the re-convalescence" (when he speaks of the Ideas) or the "diary of a philosophical work" (when he refers to his own writing). And to his most important philosophical work, he provides the following characterisation: "it consists of the stages of my thought process working upon itself, as they advanced one after the next and complemented one another". ${ }^{5}$ I should like to establish here, as the subject of my consideration, the assumptions that lie behind this sort of understanding of philosophical writing. Thus, I intend to treat the Ideas by Brzozowski as a pretext for examining the philosophical motivation of this kind.

We begin with these questions: Why is it that an author's biography the portrait of an individual life, differentiating each of its aspects - should subordinate reality to philosophical thought? Do we expect that the author renders an account of what kind of man he is, and by what path he came to his convictions for every philosophical theory?

\section{The practical attitude of philosophy. Philosophy as a lawgiver of life and action needs a prac- tical genius rather than a theory. The necessity of bearing personal testimony}

Our starting point now requires a brief outline of Brzozowski's thinking about the tasks of his discipline. The point of view of our author on this subject is linked with his understanding of the meaning of philosophical history for the European consciousness, as this history had developed to his day. Brzozowski understood the history of philosophy to be the selfconsciousness of the European spirit, which, as a developing sequence, led from Kant, through classical German idealism (closed shut with Nietzsche's writings), to Marx. Nietzsche occupies a special place in this process, as it was he who, for the first time, brought to light the singular historical responsibility of philosophy, as well as its separateness from the other cultural activities of our species: it creates the values which set the course of development for the human universe. The values that emerge as a result of the philosopher

${ }^{5}$ Ibidem, p. 70. See also: pp. 75, 463 . 
having some sort of life experience then become the basis for our real activity in the world, the effects of which turn - whether or not we are conscious of this fact - into the material with which we build ourselves. Recognising the above, Nietzsche simultaneously discovered a way to express the general drift towards the self-consciousness of the European spirit in the nineteenth century. Brzozowski, who, by his own reckoning, had thought deeply about the history of the philosophy, followed this trail wilfully:

Today all threads of the cognition leading towards [philosophy] are snapping. Contemporary thinkers feel that something essential has changed, but dare not tell themselves that cognitive thought cannot be the satisfactory equivalent and the proper tool of current philosophy; that it does not suffice to know everything taught by scientific philosophy to be a philosopher, but rather, it is necessary to be born able to consciously experience existential processes. The world assumes a new shape in each man, changes take place in every man that possesses meaning on a larger or smaller scale and extends his consciousness, but only in the philosopher do these changes become aware, only he can be the conscience of the emerging world and make its becoming his own action. ${ }^{6}$

Philosophy is not a form of cognition, but rather something much more profound; it is a form of life, a form of an action in becoming. ${ }^{7}$

Universal history, as Schiller used to say, always appears to the philosopher's eye as if it were a true treasury of inspiration. Whenever the philosophical mind starts to look at history, the "instinct that searches for harmony" awakens in him, which frees historical phenomena from "the fetters of the blind fortune" and "the course of worldly events is given clear form", Bowing slightly to this classic author, we permit ourselves to notice that the

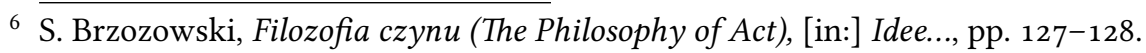

7 Ibidem, 127.

${ }^{8}$ F. Schiller, Wass heisst und zu welchem Ende studiert Man Universalgeschichte (Teutscher Merkur, November 1789). Czym jest historia powszechna $i$ w jakim celu warto ja studiować? (What is, and to What End do We Study, Universal History) [in:] Dzieta wybrane (Selected Works), selection by S. H. Kaszyński (Poznań: Wydawnictwo Poznańskie, 2006), vol. 1, p. 307. 
investigator of intellectual history, who has been gifted with a reflective temperament, and who has at his disposal facts supporting both the growing and the regression of humanity's self-consciousness, optimism and pessimism with regard to the sensible planning of its own way of life, chooses a viewpoint which will: "supply the reason with more satisfaction, and the heart with joy". For Brzozowski, who was striving to establish a thread to link Kant to Marx, the history of philosophy was the portrait of man who, throughout history, was forever recreating both himself, and that which from a naïve perspective of consciousness he had previously considered an element foreign to him; his calling also consists of activities to bring about a rational interpersonal order. What remained for the European consciousness was to measure itself bravely against this diagnosis.

Brzozowski's philosophy seeks to be a reflection on human activity in the world and its foundations - above all on the will conceived as the rational will; therefore, its drift is as practical as possible. It was the philosophers of will who, first and foremost, appeared to provide inspiration for this author - we are now obviously interested in the principle by which he selected his philosophical readings: apart from Kant, the classics of German idealism and Nietzsche, we find among them: Sorel, Bergson, Carlyle, Blondel, and Marx. The absent figure is Saint Augustine - according to Hannah Arendt, who surveyed the history of philosophy discovering the new faculty of the mind - the first philosopher of will, though it was still then perceived as the arbitrary ability to choose. Classical German idealism, which continues the Kantian concept of the will bound only by its own rule, occupies a privileged place in Brzozowski's thinking. This decision between two concepts of will - on the one hand as a liberum arbitrium and on the other as Kantian practical reason - in favour of the latter, is pivotal to the thinking of our author. Alongside his philosophical readings, English literature was also important in shaping his mind: he highly valued its brave and clear-sighted humour in perceiving the matters of this world, in whose inhospitable reality the individual desirous of giving meaning to his existence struggles with the irrational element of life. At the same time, s/he holds delusions of neither anticipating the consequences of his/her acts, nor relying credulously on the maxims s/he believes. The tradition of the German idealism and the British sense of empiricism - this connection appears merely eccentric at a first glance; would it not eventually lead us into a way of thinking about mankind which the post-Hegelian epoch tried to instil, i.e. the German historical school, Wil- 
helm Dilthey or Georg Simmel? And thus, towards the image of man as being a historical creature who makes use of the wisdom of past generations as well as the endeavours of his/her cultural circle in his attempt to live reasonably with others? In this context, the remarks of a French historian, Bertrand Saint-Sernin, are worth recalling, in which he shrewdly concluded that: "English literature absorbs all that Germans charge their Geisteswissenschaften with, as well as the moral novels, the prototype of which was Sybil by Disraeli, better than any sociological poll; it presents the state of the society or the doings of some group before the eyes of civilisation. Fictional prose thus becomes a cognitive instrument". ${ }^{9}$ However, the question of rational will and the historical man has to remain open awhile, because it seems that now we can return to our two opening questions.

We need thinking or theory to find our way through the thicket of the interpersonal matters, and lead our own lives in a responsible manner - as Brzozowski expressed it - and philosophising is not a pure, disinterested activity of the mind, but, in all respects, springs from the needs of our practice and is grounded by it. Behind this conviction, resembling a philosophy of life position, was also a certain political project, which aimed at making Polish society historically mature. And thus, "a society which would be able to create a political idea possessing solid consequences in society and life", ${ }^{10}$ for which it is necessary to learn to think in categories of reality ("terrifying but irrefutable"), and to replace "emotional thinking" with the ability to be rationally constructive in the framework of the existing political order. This thought is meant to guarantee good interpersonal order. Brzozowski was not only a theoretician, but also the author of a certain political idea, which was conservative insofar as it strove to grapple with the facts.

Philosophy is not the knowledge of something superhuman, it is the self-consciousness of humanity, its self-government. It is the creation of those thoughts which can be the converging points of the powers of the humanity. ${ }^{11}$

Humanity will be what it makes of itself, whether involuntarily

9 B. Saint-Sernin, La Raison au XXe siècle (Éditions du Seuil, 1995). Rozum w XX wieku (Reason in the zoth Century), Polish transl. M. L. Kalinowski, B. Banasiak, (Gdańsk: słowo/obraz terytoria, 2001), p. 137.

${ }^{10}$ S. Brzozowski, Anty-Engels, [in:] Idee..., p. 321.

${ }^{11}$ S. Brzozowski, Epigenetyczna teoria historii (The Epigenetical Theory of History) [in:] Idee..., p. 181. 
or in full consciousness. But whenever it should think, it strains thereby for conscious dominion over itself. ${ }^{12}$

This is thinking as a lawgiver of life and action; but what kind of thinking? As a theory established beforehand by "official specialists in guiding human affairs" - to borrow a phrase from the British humour of Isaiah Ber$\operatorname{lin}^{13}$ - or rather one based on careful observation of human behaviour both social and asocial, including one's own; philosophy has been asking itself this question for a long while. In the Platonic ideal, the philosopher entered the practical life of polis to gain a new ideal of reality, which he owed to the solitary contemplation of the orderly world of pure being. The ideal polis from the philosopher's mind would be, in the future, rendered into the material of the world we experience. "Platonic humanism (...) does not draw its political standpoint from the existing world (...) but from the idea which is its true reality" ${ }^{14}$ - as Werner Jaeger commented - however Plato's conviction that the establishment of the ideal polis is possible "protects (...) the notion of the future, for which the philosopher prepares himself, from falling foul of pure fiction, and with its possibility of being transformed into the field of reality gives the theoretical life of the philosopher this wonderful intensity which is lacking in pure science" ${ }^{15}$

"The wonderful intensity" of the Platonic theory - let us linger a while with this last aesthetic remark of the historian, which incidentally also gets down to the crux of the matter, the relation between thinking and action in rationalistic projects. The attempt to pierce through the mechanism of the world and overcome the course of its events through the powers of his/her own intellect awakens a particular philosophical feeling in the author of such an enterprise. Its charm seems to have a great deal in common with the satisfaction experienced by the audience which follows a theatrical performance, wherein both the autonomy of art and reality remain unimpaired. And, equally with the unruffled self-confidence of the author of an educational novel, who helps his protagonists to avoid the traps set by life. Brzozowski

12 Ibidem, p. 182.

${ }^{13}$ I. Berlin, The Hedgehog and the Fox (New York: New American Library, 1957). Fez $i$ lis. Esej o pojmowaniu historii u Totstoja (The Hedgehog and the Fox), [in:] Rosyjscy myśliciele (Russian Thinkers), Polish transl. S. Kowalski, afterword by A. Walicki (Warsaw: Prószyński i Spółka, 2003), p. 35 .

${ }^{14}$ See: W. Jaeger, Paideia. Die Formung des griechischen Menschen (Berlin 1959). Paideia, Polish transl.: M. Plezia (Warsaw: PIW, 1964), vol. 2, pp. 324-325.

${ }^{15}$ Ibidem, p. 325. 
called this position the "philanthropic viewpoint", rooted in our most natural, yet very delusive persuasion, that we are able to retire from the venture of life into the safe refuge of a single standpoint:

for to put life straight (...) just as the characters oft-times do in the wonderful novels of Dickens, one must have a certain, secure, established standpoint on life, something ready-made - and of course a good novelistic composition was here a confirmation of the instinct of home, a family hearth as a haven from which one can observe one's whole life in safety. Life presents itself as a logical whole only when we feel in possession of a life which is in some way provided for. ${ }^{16}$

Nothing more clearly shows us the heart of the rationalistic viewpoint than tendentious art, which wants to be useful for the society as the model of a virtuous life:

Whenever the rationalist begins to create living characters, their lives seem some obstacle to his own. He less builds them than explains why something so irrational and illogical as the living human being could come into existence. The rationalist deludes himself that aside from the game of accidental life he has a fuller life, and that this current one created by him was the reason for which the deeper one could not unfold. In fact, however, there is only a bare, white plane of abstraction beyond life in the concrete, and in creating, the rationalist feels creativity to be an obstacle; it does not develop from life and towards life, no, it is something accidental that can exist only due to the existence of that other, against which this accidental one turns itself. ${ }^{17}$

However, the intellectual satisfaction which comes as a result of being master of one's thought, one's ability to guide it skilfully and set it forth clearly, often strengthens the philosophical belief that one is correct vis a vis life, and much the same arises from the feeling that, after hard work and a long education in dialectics, one is finally on firm and indisputable ground from which to comment safely on the deeds of the actors taking part in the

\footnotetext{
${ }^{16}$ S. Brzozowski, Ztudzenia racjonalizmu (The Illusions of Rationalism), [in:] Idee..., p. 411.

${ }^{17}$ Ibidem, p. 410.
} 
games of history. This was the philosophical myth of the "homestead-refuge" which historical researchers - professionals or simply sufficiently sagacious amateurs who turned towards historical studies for political, ethical, or anthropological instruction - recognised as a truly hazardous illusion. Brzozowski called it the "poisoned food" which "while nourishing the victors" simultaneously prepares their future defeat. "In historical events one best observes the prohibition to eat from the tree of knowledge", Tolstoy once said. To rationally plan our affairs in the world we obviously need to know its rules; however, such rules are not obtained by escaping from life. This practical genius is of more use here than any "well-composed theory": the art of scenting out the situation and perceiving its various sides, putting oneself in the place of the other, a sense of moderation which during a clash of arguments allows us to maintain a peaceful co-existence and simple, oldfashioned tact. For matters involving polis, Aristotle advised phronesis, understood as "far-sightedness", a "faculty for passing judgements", a "cleverness in judgement", or a "practical wisdom", which one could learn only by living and trying out his principles in reality. How much these ideas are actually worth, and what, in fact, the values are which give reasons for our behaviour can be revealed only by carrying them into effect. At the moment when as it seems that we are beginning a new undertaking as sensibly as possible, we still have no idea what indeed we are attempting. Only life is capable of showing what, in all these schemes, was a lasting and positive force, and what was no more than dangerous illusion. How to make man a conscious "creator of himself", how to teach him to solve the problems which derive from the "necessity of his taking control over himself"18 - this was what Brzozowski considered to be the most difficult aspect of the new philosophy, which for the first time sought to take responsibility for the world it also shaped through its notions.

A philosophy which appears in the public space as a "legislator of life, and its architect" should first vindicate its authority to play this part. He who seeks to influence the course of events also affects other people through his own actions and has to provide evidence of being entitled to do so. This necessity of bearing personal testimony to one's character, and not only to prove one's philosophical professionalism, was treated as almost obvious by those minds in which Nietzsche's teachings met with some response; Brzozowski belongs to their rare circle.

${ }^{18}$ S. Brzozowski, Epigenetyczna teoria historii (The Epigenetical Theory of History), [in:] Idee..., p. 182. 
In On the Genealogy of Morality the question is put: "Could there be enough pride, courage, ingenuity, self-confidence, will to spirit, will to responsibility, and freedom of will by now that from here on the philosopher can indeed exist upon the earth?" 19 The philosopher, and therefore, "the man of the greatest responsibility, in whose conscience lies the whole development of humanity", ${ }^{20}$ the figure ready to take on the "great responsibilities". Nietzsche introduces the notion of the philosophy as a hazardous way of life which one cannot learn, but for which one has to "be born gifted". ${ }^{21}$ This in no way means that one can get by without being self-educated, to be able to take up those tasks which measure up to one's natural talents. At any rate, ever since this point one cannot philosophise in an impersonal manner without taking responsibility for all the possible worlds which arise as a result of the values one proclaims, and for one's own existence as a fact tied to them.

He who desires to judge reality and to set its course must himself be a personality, and possess a practical understanding of it - in planning it one must be prepared for the irrational and unclear in the world, the accidental and phenomenal - in thinking one must rely on one's own hitherto experience of life. That which has genuinely been experienced by an individual then guarantees the quality of a thought which has social and ethical aspirations:

It is not enough to speak of character-worship, of the necessity of maintaining a vital relationship with the life of the nation, of understanding that it is the most profound basis for our being in the world and that our vital relation to it, which we create through our everyday real life, is the only organ of any true theoretical and practical life, if, at the same time, all our intellectual culture is based on other premises. (...) Modern culture establishes an illusion of solitude round about young minds as if nothing but abstract ideas were and could be acknowledged as real. Every thought in this book was attained by long and hard work; if the pages of it could speak they would reveal my

\footnotetext{
${ }^{19}$ F. Nietzsche, Sämtliche Werke. Kritische Studienausgabe in Einzelbänden, hrsg. von G. Colli und M. Montinari (München, Berlin/New York 1988), Bd. 5, p. 361. Z genealogii moralności, Polish translation by L. Staff (Warsaw 1913), p. 138.

${ }^{20}$ Ibidem, p. 79, in Polish edition: p. 86.

${ }^{21}$ S. Brzozowski, Filozofia czynu (The Philosophy of Act), [in:] Idee..., p. 127.
} 
years of struggle. I can say this because I would be able to show precisely and accurately the genealogy of each of the thoughts written down here. I know that every reader who feels inclined to translate thoughts into the language of the personal experiences will see that he is dealing with reality, I know that this book may be useful ... [emphasis by I. S.]. ${ }^{22}$

\section{What is biography? Biography as a way to jus- tify a theory in the field of practice as well as to allow it to act in a phenomenal reality}

The biography appeared to describe the shaping of a uniform personality over the course of an individual's life, which was at the crossroads of what existed through self-conditioning and external circumstances. As Albrecht Dihle claimed, this literary form must have come into existence because a great personality required it. In Aristotle's notion of the "energy", Georg Misch found this first impulse responsible for establishing the form by which the biography bears testimony to a historical figure's character: the essential features of the person being portraited should be shown by a skilful representation of a variety of his actions. Human nature exists only through its various manifestations. Therefore, "Not by an enumeration of characteristics, but the man's acts were to be placed on record, so that his character and nature were revealed by them. By means of this mode of seeing life in action, the abstract element associated with every description of a human being that approaches the individual from without, in the belief in characteristics fixed once for all, could be brought into as close proximity to living reality as possible within the limits of that method of approach." ${ }^{23}$ According to the German scholar, this was the method of portraying the great personalities, which allowed the ancient biographies to both morally and artistically influence life.

The biographical story takes as its material the deeds which make up an individual existence, and, in this way, makes it possible to visualise the hero,

\footnotetext{
${ }^{22}$ S. Brzozowski, Zakończenie (Conclusion), [in:] Idee..., p. 463.

${ }^{23}$ G. Misch, A History of Autobiography in Antiquity (London: Routledge\&Kegan Paul Limited, 1950), Vol. I, p. 292. The first sentence comes from a book by F. Leo, The History of Roman Literature: Die griech.-röm. Biographie (1913), vol. I, p. 99.
} 
while also - through its telling the story of his struggle with fate - allows us to ascertain if we are dealing with a character who is ready to act and "to take the great responsibilities"; if it is someone trustworthy, serving as an example to be followed. As empirical evidence, one's own biography recommends one as being eligible to go forward to others with a project to bring about defined moral, political, or social consequences. Political thinkers have known for ages how valuable such personal testimony can be for carrying out changes desired in the sphere of the social practice. Thucydides, who wished for his own model of politeia to be a creative historical power, used as we know - fictional speeches of the leading Greek figures. For, in our practical life, in which feelings play as much a part as reason, and desire steers us towards many things, we are not influenced by thoughts alone, and by appeals to the intellectual powers of mind, he who would like to guide others in this sphere of reality with fairness must produce evidence of his personal attributes, such as: moral virtues, a strong will, common sense based on his own life experiences, a stable temperament, and intuition in human affairs.

\section{Ideas by Brzozowski as a biography of thought. Bearing testimony to the author's personality}

Brzozowski's Ideas consists of his articles from the years 1907-1910, which were put in proper order by the author, and two works which were written in 1903: Filozofia czynu (The Philosophy of Act) and Filozofia czystego doświadczenia. Ryszard Avenarius (The Philosophy of Pure Experience. Richard Avenarius). The $7_{\text {th }}$ to $14^{\text {th }}$ chapters of the book and the Preface were meant for the Ideas from their inception. ${ }^{24}$ The texts which make up the prior chapters were published earlier by the author. ${ }^{25}$ However, this work does not show Brzozowski's entire philosophical path; as Andrzej Walicki noted, it includes

${ }^{24}$ These are: Pragmatyzm i materializm dziejowy (Pragmatism and Historical Materialism), Prolegomena filozofii "pracy" (Prolegomena to the Philosophy of "Labour"), Bergson i Sorel (Bergson and Sorel), Anty-Engels, Etapy sentymentalizmu (The Stages of Sentimentalism), Ztudzenia racjonalizmu (The Illusions of Rationalism), Alfred Loisy i zagadnienia modernizmu katolickiego (Alfred Loisy and the Problems of Catholic Modernism), Zakonczenie (Conclusion).

${ }^{25}$ These include: Materializm dziejowy jako filozofia kultury. Program filozoficzny (Historical Materialism as a Philosophy of Culture. The Philosophical Programme), (Warsaw: Przeglad Spoteczny, 1907); Filozofia czystego doświadczenia. Ryszard Avenarius (The Philosophy of Pure Experience. Richard Avenarius), (Warsaw: Gtos, 1902/1903); Powstawanie prawa (The Creation of Law), (Kiev: Swit, 1907); Epigenetyczna teoria historii (The Epigenetical Theory of History), 
neither his "struggle for world-view" period, nor the days when he identified himself with Marxism ${ }^{26}$. The Ideas - the biography of the intellect - are "an autopsy performed on my own memory," as the philosopher writes in the Conclusion to Ideas ${ }^{27}$ with the purpose of revealing others, the individual character of his thought by presenting its products (his thought "actions"), and grasping its history as if it were a coherent whole. Moreover, he gave his thought credibility by showing its process of being shaped under the influence of the problems which life set before it, ${ }^{28}$ as well as by demonstrating that by responding to them, his thought was taking on the great intellectual powers of its epoch - Kantism, Hegelianism, Marxism, the philosophy of life - and in accepting their influence, it also gave them something of its own, because by entering into conversation with them it at the same time "opened" them to each other. Therefore, even keeping the company with the best, it preserved its own identity, while always appreciating historical reality as an ethical obligation, never as pure speculation that bore no reference to life. Also to some extent, Ideas are testifying to its mistakes:

The article on Avenarius quite accurately represents my mental state of hopeless spectatorship. The Philosophy of Act (Filozofia czynu) was an early attempt at setting up a point of departure from that seemingly hopeless situation. I have realised where

(Warsaw: Przeglqd Filozoficzny, 1907); Przyroda i poznanie (Nature and Cognition), (Warsaw: Przeglad Społeczny, 1907); Filozofia czynu (The Philosophy of Act), (Warsaw: Biblioteka Samokształcenia. Dwutygodnik, 1903).

${ }^{26}$ Compare: A. Walicki, Filozofia dojrzałości dziejowej (The Philosophy of Historical Maturity) [in:] S. Brzozowski, Idee..., pp. 8-9.

${ }^{27}$ S. Brzozowski, Idee..., p. 463.

${ }^{28}$ The fundamental question here seems to be the "youthfulness of Polish civilisation" he deeply felt. The feeling that Polish thought is irrelevant to the "long-lasting and generally developing problems of the life of the species". The fact that "we do not want to measure ourselves by that great yard-stick" (Pamiętnik..., p. 126, 127.) "Every reasonable Pole must today feel the same: that our thoughts are mouldering away overnight. They can not withstand the touch of air and earth - the air and earth we and our fathers have deserved the only earth for us" (Pamiętnik..., p. 91). A personal problem dealing with the ability to affect national reality is also important: "Despair steals in through every crack; despair and discouragement. At this moment nothing connects me to life - I am alone, even if I know that I can hold sway over that abstract knowledge, it does not want to come into being, to turn into a feeling" (Pamiętnik..., p. 91). What then were the conditions which would be necessary for the historical creation? The manner in which Brzozowski asked this question and his answer to it recall Nietzsche's remarks from the second of his Untimely Meditations - our ability to shape the world depends on the way we create ourselves through history. 
the salvation lies, I know that the escape was in understanding the active nature of thought, but this conviction was then only knowledge, and my thought was in no way made utterly concrete, of the life which springs forth from action. I nonetheless expected what was foundational and defined its meaning: a vital attitude towards life. This is also why this article was both so wide-ranging in intention, and so abstract in execution.

(...) I always saw Marxism as nothing but theoretical knowledge, showing that the world could be thought of as action; yet it was not my action.

(...) Beyond its [Marxism's] limits remained my "I", which may have even experienced itself to be the creator of theoretical thought, but still not the producer of its own reality, and therefore felt less or more unsatisfied and hopeless. That "I" made various efforts to deepen Marxism, working ceaselessly on the misguided task of affecting change in its own vital feeling with nothing more than its intellectual powers and logic. ${ }^{29}$

This was also to ensure others that they were dealing with a truly mature personality - a thought which, in all seriousness, was putting itself to the test against various philosophical systems, so as to gain an intellectual independence after consecutive efforts and disappointments. In accordance with the model of character formation whose classical pattern was established by Goethe, it was only in this way that a spiritual independence was attained, which provided a basis for acknowledging that a thought was ready to take responsibility for the actions it might inspire, and that it might be a socially useful, guide in new directions. The personality is the sum of its own tendencies and conscious work on itself, as well as the impact of life surrounding it, which requires an individual response. Only that which has been genuinely experienced by the individual might serve as theory for subsequent action and be instructive for others. Only that which has been personally attempted in one's own life can be considered finally conquered - a philosophy is not invented at will, or obligation-free:

We can only replace what we have mastered; we can not consider liberated of one belief, method, theory or form of culture

${ }^{29}$ S. Brzozowski, Idee..., p. 74, 76. 
- as long as we don't realise how that stiffened, lifeless function came to be in the first place, as long as we have not learned to perform this function freely and at will.

Any disrespect shown to a philosophy which does not systematically and creatively critique it goes hand in hand with submitting to the influence of ideas and viewpoints which are merely random. (...) To consciously convert life into the work of an individual; this is what is essential and most profound in philosophy, and there can be no talk about an abandoning of philosophy which would not involve giving up consciousness as well. ${ }^{30}$

The personal factor must take part in a philosophy which would like to serve practice - that is why Brzozowski's work used the form of the biography, which always speaks of individuality. If our object is to make reality come closer to our ethical requirements through our thought, it must first be shown that the legislator is a great personality. And that the idea now being given as a measure for empirical world has been verified via his own example - it has created a true figure. The question of personality is undoubtedly one of Brzozowski's most important themes. In his Diary we find the following remark:

The first general assumptions of my critique came into being with my reading of Taine and my love for him. Then, there was a period in which Nietzsche influenced my critical thought the most. (...) Sorel led me out of that state. Sorel, Bergson and Carlyle, but the ethical core, the notion of self, personality - the summit, the star marking out the rules of all my efforts remained clouded over (...) by the feeling that there was a gap between the thought postulate and its organ, so that I am unable to develop my own postulate. (...) That is just why I think about the mature section of Ideas with such great pleasure, why I am so attached to this book, because it was the first in which this disgrace and flaw were absent. ${ }^{31}$.

The biography, as we well know, is both the story and creation of an individual on the basis of the actions s/he performed, attested to by historical material, memory retained by a community, and the artistic talent of the

$3^{0}$ S. Brzozowski, Prolegomena filozofii "pracy" [in:] Idee..., pp. 237, 238.

${ }^{31}$ S. Brzozowski, Pamiętnik, p. 129. 
historian telling us the whole story. Its subject is an individual life, which, over its course, more or less consciously gave itself a shape. The biography is therefore "artificial" in a double sense. Its protagonist - a figure in some way distinguishing him/herself - is always a by-product of his/her own acts, which carved into a spiritual mould what was given as natural, but also of the historian's exertions: a combination of documents recounting the protagonist's accomplishments and the imagination of the researcher. Similarly, the biography of one's own thought is a creative act in a double sense, through which one gives oneself distinguishing features. The personality which appears before us is not found ready-made, but is a creation that what was attained through a conscious creative process - it is an act, not a substance.

The Ideas by Brzozowski is a philosophical work which purposely assumes the form of a biography of thought, because there is no better way, in the field of practice, to justify a theory on interpersonal relationships than personal testimonial. It is not also any means superior to narrative for allowing thought to act in a phenomenal reality.

\section{Philosophy as biography of thought. Some his- torical reasons for understanding philosophy as a form of a biography of thought.}

However, there are the other important reasons which compel us to appreciate the biography of thought in its role as a philosophical project, which very consistently derives from the development of philosophy, and is not merely a result of the formal inventiveness of the author.

It maintains, for instance, close contact with those anthropological ideas which were introduced by the pedagogical thought of the German classics: by Lessing, Herder and, above all, Goethe, but also Kant, in his concise treatises on the philosophy of history, Fichte and Hegel. We may term it a dynamic formulation of human nature - what Thomas Mann would later call the quintessence of humanism: "a drift towards the state when man reforges himself from being some indistinct product of nature into a clear creation of his own makingdoing, and thus of reason, and, in this way, fulfils his human duty and calling" ${ }^{2}$. The writer's comment was made with the reference to a

${ }^{32}$ T. Mann, Goethe und Tolstoi. Zum Problem der Humanität (Berlin: S. Fischer, 1932). Goethe i 
remark by Goethe himself from a letter written to Lavater (September, 1780) on his famous educational novel: "the desire to raise as high as possible the pyramid of my being, whose foundations were given to me and reinforced; this desire stands high above everything" 33 .

The Enlightenment owed the idea of man as a historical creature to Herder, but it was Goethe who made education the crucial question for understanding man, in his pedagogical composition Wilhelm Meisters Lehrjahre und Wilhelm Meisters Wanderjahre, the story of educating an individual into a personality, through the independent development of its own inclinations, as well as its being guided by the Pedagogical Province to fulfil its obligations to its neighbours. This work, after all, is the poet's response to his own admonition: "the proper study of mankind is man"; this is both an anthropological and an ethical project, and one might indeed wonder if Goethe was not brilliantly presaging that it was literature, more than dry philosophical treatises and abstract thought, that could be a useful instrument in realising this. From the viewpoint of Wilhelm Meisters Lehrjahre und Wilhelm Meisters Wanderjahre, human nature boils down to personality - internalising high moral values and obtaining the intellectual independence that allows the individual to overcome its natural particularism of practical interests and co-operate in a rationally organised society - in the full sense of the word. However, it should be added at once that - "to overcome" does not mean "to relinquish" any professional, social, historical etc. definition. Because, as Goethe said: "every life, every act, every art should be preceded by a craft, which is acquired only by setting limitations" 34 . According to our author, both historical and cultural conditions seem necessary for the existence of the universal.

If we are prone to see personality as human nature in the full sense of this word, it is tantamount to our recognising man to be an unsettled creature in his initial empirical state, possessing no more than the natural disposition to produce "himself". Given the fact that making himself is his own task, man

Totstoj (Goethe and Tolstoy), Polish transl M. Kłos-Gwizdalska. [in:] Dostojewski z umiarem $i$ inne eseje (Dostoyevski in Moderation, and Other Essays) (Warsaw: Muza SA, 200o), p. 107.

33 See: E. Trunz, Anmerkungen des Herausgebers [in:] Goethes Werke (Hamburg: Hamburger Ausgabe in 14 Bänden, 1968), Band VII, p. 671.

${ }^{34}$ J. W. Goethe, Wilhelm Meisters Lehrjahre, 7. Auflage [in:] Goethes Werke (Hamburg: Hamburger Ausgabe in 14 Bänden, 1968), Band VII; Wilhelm Meisters Wanderjahre, 8. überarbeitete Auflage [in:] Goethes Werke (München 1973), Band VIII. Wilhelm Meister, Polish transl. P. Chmielowski ( Warsaw 1893), p. 592. 
requires education - moulding his mental powers by himself, while taking his social and cultural surroundings as a measure and an influence. Human nature is therefore the combination of "natural" human capabilities with that whichat was of the historical origin, arising from a complex process of the education.

In his writing on the philosophy of history, Kant set forth this thought in the language of philosophical concepts - he said it was Nature understood as Providence that made a man a creature in which certain biological conditions exist alongside free will and the faculty of reason, and whose destiny is to be overcome his "naturalness" through shaping his mental powers (which is possible only through a social way of living with others, and coming to grips with various individual points of view). This "naturalness" is not his actual nature, but the stratagem which Nature-Providence uses to force him to make himself whom he should be. However, according to Kant, this plan of Providence does not affect the life of concrete individuals, but of the whole species, and what's more, its success is very uncertain. How well-grounded this uncertainty actually remains in the context of the assumptions of Kant's philosophising on history is a matter which can not be taken up here. Nevertheless, there is an interesting consistency that appears in philosophical reflection - the growing clarity of a way of thinking about man that takes historical process into consideration and introduces dynamics into his philosophical image. ${ }^{35}$

Let's set this little-known historical aspect of Kant's thought aside. In the field of the philosophy of history, Fichte takes up his transcendental point of view and considers history as if it were the development of spiritual events springing from the free activity of the absolute $I$ - understood not as a substance, but as a pure act and creative power. Fichte found the dynamic categories that allowed him to describe the course of the history in the acts of the transcendental subjectivity. The structure of history is identical to the energetic structure of the consciousness. The pure ego manifests itself through empirical concrete selves - conceived as the ability to give definition to itself - its essence derives from its free activity. By its nature, it is the

35 See also: E. Paczkowska-Łagowska, Natura ludzka a historia. Refleksje w nawiazaniu do pism antropologicznych Immanuela Kanta (The Human Nature and the History. Some Remarks on the Anthropological Works by Immanuel Kant) in the collection of articles: Wyjaśniać i rozumieć. Księga dedykowana Profesorowi Zbigniewowi Kuderowiczowi (Explaining and Understanding. A Book Dedicated to Prof. Z. Kuderowicz) (Białystok: Uniwersytet w Białymstoku, 2006). 
history of its own creations, and it does not know itself before its act is committed. As Berlin remarked, the new, strong idea of man thereby appears to the European consciousness - a tragic hero striving for self-realisation at all costs. ${ }^{36}$ This idea has, of course, its peculiar political and ethical consequences.

Fichte revealed the reality which occurs to the consciousness as having emerged from setting up and setting against, and their higher unity in the transcendental subject. Hegel passed the remark on the authority of Kant that development in both of these fields, the subjective and the objective, might be expounded in terms of conceptual relations. However, as Wilhelm Dilthey pointed out: "the conceptual system he was looking for did not aim at giving aspects of life an abstract formulation and arrangement; he rather strove for a new system of concepts wherein development would become fully comprehensible. (...) the whole domain of history became his object. He was everywhere searching for activity, progress, whose essence was always embedded in conceptual relations. This is also why history was converted into philosophy." ${ }^{37}$ In the above excerpt, Dilthey circumspectly points out that the Hegelian attempt to explain historical goings-on via concepts leads to "the impoverishment and fossilisation of life in history" 38 - historiography turns into philosophy. Everyday life, which we know from our experience, lies outside of Hegel's interests; as he wrote: "occurrences which possess a universal significance (...) I usually see as a pretext for universal considerations in the face of which anything singular and near at hand, regardless of how much it may absorb the emotions, recedes into the background." 39 However, for Hegel, history changes into philosophy in another sense as well,

${ }^{36}$ I. Berlin, The Sense of Reality. Studies in Ideas and their History, (London: Chatto \& Windus Limited, 1996). Zmyst rzeczywistości. Studia z historii idei, Polish transl. M. Filipczuk (Poznań: Zysk i S-ka, 2002), p. 237.

${ }^{37}$ W. Dilthey, Der Aufbau der geschichtlichen Welt in den Geisteswissenschaften, Plan der Fortsetzung zum Aufbau der geschichtlichen Welt in den Geisteswissenschaften, Zusätzse zum Aufbau der geschichtlichen Welt [in:] W. Dilthey,Gesammelte Schriften (Göttingen: B. G. Teubner Verlagsgesellschaft, 1973), 6. unveränderte Auflage, VII Band. Budowa świata historycznego $w$ naukach humanistycznych (The Formation of the Historical World in the Human Sciences), Polish transl. E. Paczkowska-Łagowska (Gdańsk: słowo/obraz terytoria, 2004), pp. 47, 48.

${ }^{38}$ Ibidem, p. 127.

${ }^{39}$ Letter to Niethammer from 1816. See: K. Löwith, Von Hegel zu Nietzsche. Der revolutionäre Bruch im Denken des neunzehnten Jahrhunderts (Hamburg: Felix Meiner Verlag, 1995). Od Hegla do Nietzschego. Rewolucyjny przełom w myśli XIX wieku, Polish transl. S. Gromadzki (Warsaw: KR, 2001), pp. 262, 263. 
one of greater interest to us here; this was because of the regard he held for what is in mid-course, and dynamic in life. The Phenomenology of Spirit was sometimes called a Bildungsroman, not unlike Wilhelm Meisters Lehrjahre und Wilhelm Meisters Wanderjahre, ${ }^{40}$ due to its presenting the story of the self-education of the spirit entering into historical existence (the empirical world emerges from itself and stands face-to-face as a self-in-itself), with the purpose of obtaining freedom and self-knowledge at the end of a long learning process. This is the only possible path which leads to becoming cognisant of one's own nature, because:

knowledge is the cognisance not only of itself, but also of its negation, of its limit. To become conscious of one's own boundaries means to be able to sacrifice oneself. This act of the self-sacrifice is the exteriorisation in which the spirit presents to itself its becoming a spirit in the form of free, accidental [historical] event, seeing its pure self as time outside of itself, and its being as space. This becoming in space - or nature - is its vital, immediate becoming; nature - the exteriorised spirit - is in its existence nothing other than the eternal exteriorisation of its own permanent existence and the motion which restores the subject. ${ }^{41}$

Then, in the Encyclopaedia of the Philosophical Sciences, we read:

The fact that a pre-division takes place in the idea (Das SichUrteilen der Idee) into both phenomena [the nature and the spirit], defines them as its (the self-recognising reason) manifestations, and there occurs the return to its unity by making what is moving ahead and developing the nature of things, the concept, and this movement is to the same degree the activity of cognition - the eternal idea being in-itself and for-itself, as the absolute spirit is perpetually setting itself in motion, producing itself and relishing in itself. ${ }^{2}$

$4^{0}$ For instance: J. Hyppolyte, Genĕse et Structure de la Phénoménologie de l'Esprit de Hegel (Paris: Éditions Montaigne, 1946).

${ }^{41}$ G. W. F. Hegel, Die Phänomenologie des Geistes, hrsg. von J. Hoffmeister (Leipzig 1949), [563, 564]. Fenomenologia ducha (The Phenomenology of the Spirit), Polish transl. A. Landmann (Warsaw: 1963), vol. 2, pp. 426, 427.

${ }^{42}$ G. W. F. Hegel, Enzyklopäedie der philosophischen Wissenschaften [in:] Werke in 12 Bänden (Frankfurt/M: Suhrkamp, 1970), Bd. 10. Encyklopedia nauk filozoficznych (The Encyclopaedia of the Philosophical Sciences), Polish transl. S. F. Nowicki (Warsaw: PWN, 1990), p. 584. 


\section{Biography of thought as a dynamic form of ex- pounding the historical spirit and life}

We might now naturally pose the question of the form of expounding that which to itself is presented as being a space-time process (history). Neither a definition nor a simple enumeration of the signs of activity seem to suffice here - that which is becoming and self-creating requires a dynamic means to express itself, and the biographical narrative proves exactly such an energetic tool. If philosophy - "the thought which thinks itself" - is an idea, and thus the uniform totality of self-knowledge from all its earlier stages, it needs an expression for itself so as to be more than an "empty name". Similarly, any "characterisation" would never reveal the personality of a protagonist, but only the whole story of his vicissitudes. If the Hegelian spirit is by its nature historical and is its various historical manifestations of itself, then the biography, on account of its ability to show both the unity and the diversity of the aspects of one life - the subjective and the objective in their mutual connection - appears as an adequate tool for its philosophical expression. The meaning of the biography - as Dilthey once put it - lies in that "binding of life in its multiplicity with historiography". ${ }^{43}$ Hegel distinguished himself with his brilliant sense of history, but his thinking on the historical world, the basis of which was the spirit as an over-subject and dynamic power, was still a metaphysical viewpoint. It was Hegel, however, who led philosophy to change its perspective on the historical; in consequence, the standing of historiography (and within it of biography) takes the higher rank as an instrument of philosophical anthropology. The philosophy of life paid particular attention to this literary form - Dilthey was of the opinion that biography allowed us to acquire "deeper insight into human life and its individual figures", and provided philosophy with categories which would make it possible to grasp the experience fuller than scientific methods. It provides a glance into the innumerable ways that the events making up a temporary human existence can be systematically set in order. It also presents the course an individual life takes to construct itself as a nexus of events. On the other hand, Nietzsche considered the usefulness of the biography for the creative life as a method of mastering one's own past, and which gives man power over his own future; which allows him to introduce his own project into it. The past is the most dangerous adversary of the will, which seeks to

${ }^{43}$ W. Dilthey, Budowa świata historycznego w naukach humanistycznych..., p. 251. 
establish the future on the basis of new values. The second of the Untimely Meditations: On the Use and Abuse of History for Life is a classic reflection on this question. Let us now take both of these viewpoints together, as well as their significance in the epoch of empirical philosophising.

Through an examination of existing types of the world-views, Dilthey concluded that their source was the problem of life, which flowed from reflective individual's personal sensation of her own vitality: the experience of birth, death, the passing of the generations, family kinship, fighting with others for the objects of our desires, and the experience of one's own frailty in the face of the constancy of the nature. These do not by any means have the "clinical questions of the intellect" at their foundation:

Philosophy produces an awareness of the unity of our experiences, our activities, our very life; it raises this consciousness to the level of the conceptual thinking. The unity of this whole, the unity of what comprises it: objects, experiences of structure and the law, states of living, aims and goods - that web of nettlesome and fascinating problems, intellectual pleasure and pain of the imperfection, contradictions: this is the riddle of life; the peculiar, dark, terrifying subject of all philosophy. ${ }^{44}$

\section{Biography of thought as a place where man develops orientation in the world}

The biography (the autobiography as a coming-to-terms with one's own life and thought is its variant) - which was given the rank of philosophy by Hegel's authority, in the days of the latter's definitive leave-taking from metaphysics - becomes a place where man develops some orientation in the reality based on past actions, which were written down, the values assigned to events, the significance given to concrete aspects of his own life, a multitude of tiny facts. And through creating himself in it (the biography/auto-

${ }^{44}$ W. Dilthey, Das Wesen der Philosophie [in:] Gesammelte Schriften (Leipzig-Berlin: Teubner Verlag, 1924), Bd. V; Die Typen der Weltanschauung und ihre Ausbildung in den metaphysischen Systemen [in:] Gesammelte Schriften (Leipzig-Berlin: Teubner Verlag, 1931), Bd. VIII. O istocie filozofii i inne pisma (On the Essence of Philosophy and Other Essays): Pojeccie filozofii (Essence of Philosophy) [IIB], Polish transl. E. Paczkowska-Łagowska (Warsaw: PWN, 1987), pp. 204, 205 . 
biography) as a particular character, he builds a foundation for himself to plan the future. Brzozowski thus characterises the post-metaphysical situation of the consciousness:

The problem stands thus. History has provided us with a very multiform spiritual culture. Different people are moved (or rather set themselves in motion and thereby think they are moved) through various beliefs. What is the most important here is not the sort of belief, but the things these people do. (...) Proud philosophy reveals its limitations. Do something, just do something! But what?

(...) If the life is our fundamental reality, if a man is a giant unceasingly struggling with the elements of nature, he must eventually become his own legislator. He no longer feels satisfied with being moved by thought: he realises that thought must be something that differs from the custom of serving soldiers a round of rum before battle, he wants thought not as just a mover, but for him to make it come true. What is such a thought which might deserve to be realised by man? Shall we randomly pull from the chaos of imaginings to search out the gods among them? (...) To realise, to create, a man can only have himself as his goal. At the very moment when the human struggle with the unknown appears to us as reality - our only aim can be the victory of man. What does "victory" mean? That a man not move like the sail of the windmill whose speed would be - if it only could think - unwound by enthusiasm and justification, but his being himself and self-consciously hold himself over the abyss. What is an act? (...) An act is what in the non-human world produces outcomes which endure and depend on our will, what in the very essence of life produces the ability to bring about such effects and to maintain this ability. Work is the only fundamental act - consciously self-governing work is perfection. ${ }^{45}$

In the post-metaphysical times, there is nothing but the empirical individual at the foundation of the historical world - the rational will responsible for its shape and dynamics. It binds itself through its own law of reason, because it wishes to be autonomous, to be free of accidental subjugation to the

${ }^{45}$ S. Brzozowski, Pragmatyzm i materializm dziejowy [in:] Idee..., pp. 210, 211. 
natural instincts and the impulses. However, this law of the reason which allows it to "hold itself above the abyss" - and thus to control itself as an undetermined being and that is open to the future - is not given in advance. Just as it does not know its nature before the latter reveals itself through an act, it must attain the right on the basis of what has already been carried out in its history, while taking into consideration the past and contemporary problem situation, thus creating for itself rules of conduct. In both of these functions - as a tool which unfolds a man's nature before him (or perhaps we should say: character) and something which lays out his future through establishing his essential features - the biography or the autobiography appears. Theory and practice intertwine, because the understanding of what happens in one life, the granting of significance to concrete facts (the result of both the lifestyle and the composition of the story), puts the man making this sort of reflection in the new relationship vis a vis himself. The biography and the autobiography respond to man's natural need to be oriented in a world where reflecting on human affairs is impossible from an extra-historical viewpoint. Having said this, it seems natural that this form of expressing and studying man's nature was used by philosophy. And so it is also in this context, and not only on account of the need to provide evidence of his morality and ability to live a good life, that Brzozowski's attempt at expounding his philosophy in the form of a biography of thought seems to be worth serious consideration.

\section{Bibliography}

1. Berlin I., The Hedgehog and the Fox (New York: New American Library, 1957), feż i lis. Esej o pojmowaniu historii u Totstoja (The Hedgehog and the Fox) [in:] Rosyjscy myśliciele (Russian Thinkers), Polish transl. S. Kowalski, afterword by A. Walicki, Warsaw: Prószyński i Spółka, 2003.

2. BERLIN I., The Sense of Reality. Studies in Ideas and their History (London: Chatto \& Windus Limited, 1996), Zmyst rzeczywistości. Studia $z$ historii idei, Polish transl. M. Filipczuk, Poznań: Zysk i S-ka, 2002.

3. Brzozowski S., Pamiętnik (Diary), with fragments of the author's letters selected and commented on by O. Ortwin, introduction by A. Mencwel, Warsaw: Czytelnik, 2000. 
4. Brzozowski S., Idee. Wstęp do dojrzałości dziejowej (Ideas. Introduction to the Philosophy of Historical Maturity), also: Ztudzenia racjonalizmu (The Illusions of Rationalism), introduction: A. Walicki, Kraków: Wydawnictwo Literackie, 1990.

5. Dilthey W., Der Aufbau der geschichtlichen Welt in den Geisteswissenschaften, Plan der Fortsetzung zum Aufbau der geschichtlichen Welt in den Geisteswissenschaften, Zusätzse zum Aufbau der geschichtlichen Welt [in:] W.Dilthey, emphGesammelte Schriften (Göttingen: B. G. Teubner Verlagsgesellschaft, 1973), 6. unveränderte Auflage, VII Band, Budowa świata historycznego w naukach humanistycznych (The Formation of the Historical World in the Human Sciences), Polish transl. E. Paczkowska-Łagowska, Gdańsk: słowo/obraz terytoria, 2004.

6. Dilthey W., Das Wesen der Philosophie [in:] Gesammelte Schriften (Leipzig-Berlin: Teubner Verlag, 1924), Bd. V; Die Typen der Weltanschauung und ihre Ausbildung in den metaphysischen Systemen [in:] Gesammelte Schriften (Leipzig-Berlin: Teubner Verlag, 1931), Bd. VIII, O istocie filozofii i inne pisma (On the Essence of Philosophy and Other Essays): Pojęcie filozofii (Essence of Philosophy) [IIB], Polish transl. E. Paczkowska-Łagowska, Warsaw: PWN, 1987.

7. Goethe J. W., Wilhelm Meisters Lehrjahre, 7. Auflage [in:] Goethes Werke (Hamburg: Hamburger Ausgabe in 14 Bänden, 1968), Band VII; Wilhelm Meisters Wanderjahre, 8. überarbeitete Auflage [in:] Goethes Werke (München 1973), Band VIII. Wilhelm Meister, Polish transl. P. Chmielowski, Warsaw 1893.

8. Hegel G. W. F., Die Phänomenologie des Geistes, hrsg. von J. Hoffmeister (Leipzig 1949), [563, 564], Fenomenologia ducha (The Phenomenology of the Spirit), Polish transl. A. Landmann, Warsaw: PWN, 1963.

9. Hegel G. W. F., Enzyklopäedie der philosophischen Wissenschaften [in:] Werke in 12 Bänden (Frankfurt/M: Suhrkamp, 1970), Bd. 10, Encyklopedia nauk filozoficznych (The Encyclopaedia of the Philosophical Sciences), Polish transl. Ś. F. Nowicki, Warsaw: PWN, 1990.

10. Jaeger W., Paideia. Die Formung des griechischen Menschen (Berlin 1959), Paideia, Polish transl. M. Plezia, Warsaw: PIW, 1964.

11. Lichtenberg G. Ch., Schriften und Briefe, hrsg. von Wolfgang Promies (München 1962), [B 95], Pochwała watpienia. Bruliony $i$ inne pisma, selected and translated to Polish by T. Zatorski, Gdańsk: słowo/obraz terytoria, 2005 . 
12. Löwith K., Von Hegel zu Nietzsche. Der revolutionäre Bruch im Denken des neunzehnten fahrhunderts (Hamburg: Felix Meiner Verlag, 1995), Od Hegla do Nietzschego. Rewolucyjny przełom w myśli XIX wieku, Polish transl. S. Gromadzki, Warsaw: KR, 2001.

13. Mann T., Goethe und Tolstoi. Zum Problem der Humanität (Berlin: S. Fischer, 1932). Goethe i Totstoj (Goethe and Tolstoy), Polish transl. M. Kłos-Gwizdalska [in:] Dostojewski z umiarem i inne eseje (Dostoyevski in Moderation, and Other Essays), Warsaw: Muza SA, 2000.

14. Misch G., A History of Autobiography in Antiquity, London: Routledge \& Kegan Paul Limited, 1950.

15. Nietzsche F., Sämtliche Werke. Kritische Studienausgabe in Einzelbänden, hrsg. von G. Colli und M. Montinari (München, Berlin/New York 1988), Bd. 5, $Z$ genealogii moralności, Polish translation by L. Staff, Warsaw 1913.

16. Paczkowska-Łagowska E., Natura ludzka a historia. Refleksje w nawiazaniu do pism antropologicznych Immanuela Kanta (The Human Nature and the History. Some Remarks on the Anthropological Works by Immanuel Kant) in the collection of articles: Wyjaśniać $i$ rozumieć. Ksiegga dedykowana Profesorowi Zbigniewowi Kuderowiczowi (Explaining and Understanding. A Book Dedicated to Prof. Z. Kuderowicz), Białystok: Uniwersytet w Białymstoku, 2006.

17. Schiller F., Wass heisst und zu welchem Ende studiert Man Universalgeschichte (Teutscher Merkur, November 1789), Czym jest historia powszechna i w jakim celu warto ja studiować? (What is, and to What End do We Study, Universal History) [in:] Dzieła wybrane (Selected Works), selection by S. H. Kaszyński, Poznań: Wydawnictwo Poznańskie, 2006.

18. SAInt-Sernin B., La Raison au XXe siècle (Éditions du Seuil, 1995), Rozum wXX wieku (Reason in the zoth Century), Polish transl. M. L. Kalinowski, B. Banasiak, Gdańsk: słowo/obraz terytoria, 2001. 